\title{
Shifts in the Meaning of Sovereignty and Applicability of the Concept for Analysis of Contemporary World Politics
}

\author{
Dmitry Gennadievich Baluev ${ }^{1}$ \\ ${ }^{1}$ Lobachevsky State University of Nizhni Novgorod -National Research University, Russia \\ Correspondence: Dmitry Gennadievich Baluev, Lobachevsky State University of Nizhni Novgorod -National \\ Research University, 603950, pr. Gagarina, 23, Nizhny Novgorod, Russia. E-mail: pr@unn.ru
}

Received: July 30, 2014 Accepted: September 30, 2014 Online Published: December 30, 2014

doi:10.5539/ass.v11n3p212 URL: http://dx.doi.org/10.5539/ass.v11n3p212

\begin{abstract}
This paper deals with changing meaning of sovereignty in context of globalization. It touches upon dialectic relations between sovereignty and globalization. Attitudes towards sovereignty of different non-state actors of contemporary world politics and different states are special interest for the author. The main aim of the article is in analyzing how the changes in technology associated with globalization and creation of civil rights protection rules result in emergence of new political structures and new rules that will replace the rules and structures associated with sovereignty, examines the growing role of new actors in world politics in a multipolar world and uncertainty.
\end{abstract}

Keywords: sovereignty, international relations theory, world politics, foreign policy

\section{Introduction}

According to numerous authors, the current epoch is associated with the terms "post-realism" and "post-positivism" (Smith, Booth, \& Zalewski (Eds.), 1996). International relations were historically viewed through the prism of the state. Such approach was also dominating during the second half of the twentieth century. However, despite all efforts to become a "timeless truth" (Buzan, 1996), realism is associated with a specific historical context. According to G. Youngs, realistic tradition in international relations, its principles and orientation can be fully understood only when placed in the context of the time when they were formed. It was the time of wreckage of inter-war hopes for world peace through the League of Nations and the beginning of World War II (Youngs, 1999). Studies on sovereign state creation often interpret outside involvement in domestic politics as a force against which nationalist forces mobilize (Chong, 2011). The realism consolidation time was at the cold war epoch. Changing primary units of analysis is the feature of the new era. The evolution rides the line of the state monopoly crisis. Technological, economic, political and cultural changes in international relations are so important that some authors even offer to change the discipline name. For example J. Rosenau, proposed to replace the term "international relations" by "post-international policy" (Rosenau, 1989). G. Youngs speaks about international relations evolution to global relations (Youngs, 1999).

Nowadays the use of classical geopolitical approach to international relations analysis is becoming less popular. It is stated that in the era of globalization, national boundaries become irrelevant. Most of the post-industrial states have departed from territorial expansion as self-sufficient political objective. Instead, they focused on economic and technological development. Such events as NATO military action in Kosovo, Libyan campaign or talks about intervention in Syria also undermine the principles of territorial sovereignty and the inviolability of borders.

Another problem is that the very notion of sovereignty is western-centered. As Timo Kivimäki has pointed out, "The theory of international anarchy can possibly be supported by European, but not by East Asian, experiences. Supranational control over states seemed acceptable to Europeans; they had suffered under conflicts caused by expansive nationalism, and thus integration was greeted as a commonly accepted remedy and the foundation of a peaceful, commonly accepted normative order in Western Europe. However, since the Asian experience was different, a sense of ownership could not be infused into their normative order by simply copying the European recipe based on European experience.” (Kivimäki, 2012). 
Nowadays it makes sense to consider sovereignty only in dialectic correlation with interdependence. Only the contradictions between them give the sovereignty an inherent meaning. Preservation of sovereignty means the ability to achieve objectives despite the interdependence pressures or even using them (Tsygankov, 2000).

\section{Materials and Methods}

There is a popular question: whether the system of sovereignty is just a relic of the past? Will the changes in technology associated with globalization and creation of civil rights protection rules result in emergence of new political structures and new rules that will replace the rules and structures associated with sovereignty? Let's try to give an approximate answer to this question.

If the sovereignty rules would be replaced by other rules, this can only happen through an evolutionary process where key actors come to the conclusion that choice of new rules and institutions will benefit them. It is unlikely that in the near future key actors will make such choice, taking into account the benefits of maintaining status quo, governments' ability not to pay attention to claims in the areas where they have little influence, and the fact that sovereignty can coexist with other institutional forms (but not be replaced by them) (Baluev \& Novoselov, 2010). The so-called "gray zones" are appearing in world politics where traditional meanings of political concepts could become opposite.

Table 1. Differences between axiomatic thuths outside gray zones and reality in gray zones

\begin{tabular}{ll}
\hline "True" outside of Gray Zones & May be true in Gray Zones \\
\hline $\begin{array}{l}\text { Democracy is the best of existing political } \\
\text { regimes }\end{array}$ & Democratic rhetoric is a tool to influence traditional actors in world politics \\
\hline $\begin{array}{l}\text { Elections are the only legitimate way of } \\
\text { coming to power }\end{array}$ & Elections cause instability, \\
\hline Use of chemical weapons is criminal & $\begin{array}{l}\text { Use of chemical weapons, forbidden after the First World War in order to weaken the } \\
\text { military-political potential of Germany, whose chemical industry had a greater potential than } \\
\text { chemical industries of victorious powers - sometimes more justified, selective and humane } \\
\text { tool than use of numerous conventional weapons nowadays considered legitimate; }\end{array}$ \\
\hline $\begin{array}{l}\text { Drug production is by its nature a threat to } \\
\text { international security }\end{array}$ & $\begin{array}{l}\text { Fight against drug production is like the alcohol "Prohibition" in the U.S. a source of } \\
\text { corruption and a pretext for interfering in internal affairs of countries, whose economy } \\
\text { depends on it, and whose cultural traditions do not contradict this type of activity; }\end{array}$ \\
\hline $\begin{array}{l}\text { Organized criminal groups are the cause } \\
\text { anarchy and instability }\end{array}$ & $\begin{array}{l}\text { Organized criminal groups in the context of weak state institutions serve as social structure } \\
\text { performing important social functions and their existence is not contrary to interests of large } \\
\text { population segments }\end{array}$ \\
\hline
\end{tabular}

Arms trade, being a necessary evil, should

be implemented only within the Arms traffic within a "Gray Zone" should be carried out according to rules different from ones frameworks once and forever fixed by of the rest of the existing world system existing international regimes

Nevertheless, even the evolutionary changes in the sovereignty nature lead to revision of the state role as the main actor in world politics and rethinking the concepts of "foreign policy" and "national interest". International law has been also adapting to the new environment. While globalization does not make governments outdated, many analysts have concluded that power distribution in international system framework becomes more diffused (Lake, 1999). In the current environment, the state is not always the exclusive unit of analysis. However, the state uniqueness was a theoretical model, based on the Westphalian interpretation of international relations. States continue to be the main actors in the international system. Other actors' (including transnational corporations and international organizations) performance is largely determined by decisions taken by governments. All states share a minimum agenda of preserving territorial and political integrity. The specific strategy pursued by a state is determined by structural factors - power distribution in the world system and the place of the state in this distribution.

\section{Results}

The state monopoly is also prejudiced externally. Sovereignty itself is no longer a guarantee of international legitimacy (Held, McGrew, Goldblat, \& Parraton, 1999). Military force was the basis for evolution of institutional forms of modern sovereign nation-state. Independent ability to defend the territory by military means was the basis of the modern concept of sovereign state. The current military globalization also puts national sovereignty and autonomy into question.

Other states, international organizations, private actors, such as NGOs, movements for civil rights or companies occasionally try to deny the state monopoly for organized violence. As consequence, attempts to consider rebel 
movements' claims as legitimate and to conduct a dialogue with them. An example is the international recognition of the Palestinian state. Such actions violate the principle of non-interference in internal affairs of other states.

The idea of privatization of the foreign policy is even more radical than privatization of some elements of the defense policy. In the Western political tradition the foreign policy was the most honorable part of the policy. It was aimed to protect public interests defined by raison d'etat. Privatization means lobbying for foreign governments and private companies and using private channels for negotiations on resolving conflicts (South Africa and Mozambique).

Global forces "from above" (economic, technological, and cultural) are forcing states, even strong states, to review the concept of sovereignty. The maneuver space for weak states is significantly limited by their internal conditions and by more powerful states. Moreover, many states are facing the challenges of the "from below" as groups that define themselves as people or even nations, demand greater rights to self-determination

States (even insufficient ones) have not become outdated institutions. They are still quite influential and important sources of power in the world system. However, they have increasingly become "empty" or "defective" institutions (Strange, 2000).

Along with reduction in political leaders' ability to control situation in their countries, globalization also reduces their willingness to accept responsibility. While states remain sovereign, a number of their leaders prefer delegating some of their powers "to the above" - to international institutions because of the need for new rules for global transactions management and global threats withstanding. The power authorization are also transferred "to the below", to local groups and individuals, who use new information technologies, receive information directly from its sources and become newsmakers themselves (Baluev, 2013). The power also escapes to a wide range of non-governmental organizations - from corporations to environmental organizations. Within the states pluralism is becoming the norm. Pressure groups in one country may cooperate with similar groups in other countries. Because of this, the role of main political actors is transferred to global policy networks constituting alliances of government agencies, international organizations, corporations, non-governmental organizations and other community groups (Reinicke, \& Wolfgang, 2000). A characteristic feature of modern development is the transition to a new stage of the formation of an innovative society, to build an economy based on the generation, distribution, transfer and use of knowledge (Avralev \& Efimova, 2014). Ability to adapt capacity to the constantly changing environment is becoming the leading trend, the main source of material prosperity of civil society (Avralev \& Efimova, 2013). Information technology allows these networks to grow and exert an influence that is disproportionately large compared to their sizes (Wilhelm, 2000).

\section{Discussion}

The new system of power relations is characterized by pluralism of sources of power. The nation-state is one of these sources (Castells, 1998). The old mechanism - international relations of national governments - is increasingly losing its relevance, and the present configuration of power in the world becomes the attribute of the other, more influential institutions.

The fundamental change in the nature of interstate rivalry means that in the past states fought for control over territory and resources located in their territories. Currently, states are increasingly competing for market shares in the world economy. In this rivalry territory is no longer a basis for social wealth production. Natural resources can help in this rivalry, and their lack worsens the situation in the state. However, such aspects are no longer major determinants.

The states are now competing for capital-raising to carry out their development programs. Markets transnationalization has further strengthened the position of global corporations. It enhanced the need for states to be attractive for corporations. There is a disproportion. Some states are much more successful than others in use of their powers and resources in relationships with corporations. At the same time the "diplomatic relations between states and corporations" are increasingly prevalent over interstate diplomatic relations (Underhil \& Geoffrey, 2000). Development of higher education, strengthening international ties between leading educational centers is a powerful tool for the implementation of public policy (Avralev \& Efimova, 2013). As a consequence of such to a greater degree economic competitive states nature and behavior have changed. Industrial and trade policies are more important than defense and foreign policy. States are increasingly looking for trade partners, not military allies. Some of these partners are other states. Other partners are foreign companies. The state has to share authorities in economy and social life with other entities, including not only transnational corporations, banks, accounting and law firms, international institutions, but also NGOs. Inside the state powers are increasingly divided between the central government and local authorities. 
Traditional subjects of social interaction - nation-states - are losing control of the situation, and new subject the "world community" - is far from being formed. The emerging problems have crossed national borders. But in political and economic terms, the world is still based on etatist principle.

The new environment changes the very concept of national interests and their place in the foreign policy-making process. Interests are not prescriptions; they are created through social interactions. Domestic policy can play an important, often decisive role in setting national objectives and interests (Thurman \& Efimova, 2014). However, domestic politics and local conditions cannot explain a number of declared interests and political decisions.

State interests are defined in the context of internationally recognized rules and understanding of what is acceptable. This context itself is changing by lapse of time. The change in internationally recognized rules and values cause changing state interests, and states behavior (Finnemore, 1996). Newly powerful states are beginning to advance their own ideas and agendas for global order. Old international system could give way to a more contested and fragmented system of blocs, spheres of influence, mercantilist networks, and regional rivalries (Ikenberry \& John, 2011).

In addition, the state is increasingly trying to apply its own laws to citizens and events taking place outside its borders. In the field of criminal law, the United States and several other countries try to apply their own laws to processes abroad (for example, terrorism and drug traffic), based on consequences of such processes for themselves. The drift to judicial exterritoriality can be retraced in antitrust, commercial and finance law. Growing extraterritorial application of national laws reflects globalization, as it is a new way of intergovernmental cooperation. Individuals and groups were recognized as subjects of international law on the basis of agreements such as the Charters of the Nuremberg and Tokyo Military Tribunals (1945), the Universal Declaration of Civil Rights (1949), the International Covenant on Civil and Political Rights (1966) and the European Convention on Human Rights (1950) (Held, McGrew, Goldblat, \& Parraton, 1999).

According to the traditional principles of the Westphalian system, civil rights are strictly an internal affair of the states. However, since the prohibition of piracy in the eighteenth century and slave trade in the nineteenth century, this principle has become diffused. Some authors are even proposing that "true" subjects of international law are really human individuals not sovereign states (Waldron, 2011). The phenomenon of humanitarian intervention may serve as reflection of reducing the role of states (especially insufficient ones). Humanitarian intervention could be recognized if it is approved by the UN. The conflict in Kosovo has established new rules for humanitarian intervention.

Now we can even see an emergence of a "fragile ideological coalition with members of both the human rights and hard security communities advocating for more robust sovereignty-limiting doctrines" (Brooks, 2012.).

These tendencies lead to push pack from some of newly rising states. The BRICS form a coalition of sovereign state defenders. While they do not seek to form an anti-Western political coalition based on a counter-proposal or radically different vision of the world, they are concerned with maintaining their independence of judgment and national action in a world that is increasingly economically and socially interdependent (LAÏDI, 2011). Most of them are exponents of the pro-sovereignty, anti-interventionist approach to international politics. They emphasize inclusive cooperation among developing countries and are disinclined to confront autocratic leaders (Carothers \& Youngs, 2011).

\section{Conclusion}

As we can see, classical Westphalian meaning of sovereignty is not sufficient any more for valid analysis of international politics. The term retains its heuristic value, but it's meaning is in the process of constant modification. Different societal forces from the spread of social media mediated information interactions to rise of migration flows (Rykhtik, 2012) are contributing to this process. Influential new actors of world politics however are more inclined to use sovereignty principles when it fits them, not abandon sovereignty altogether. In addition most of newly industrialized states are exponents of the pro-sovereignty, anti-interventionist approach to international politics. (Sergounin, 1996) All this draws a conclusion that sovereignty strengthening can gain a new momentum, but the meaning of the sovereignty under the new conditions will differ from traditional Westphalian one.

The Western way of life and western state model are only attractive as long as they are perceived to be desirable and preferable to other alternatives. Should the capitalist democratic world system enter a pronounced downturn, this may no longer be the case. In South East Asia economic development has only strengthened authoritarian forces. 
Opposition to western cosmopolitan values are strong in East Asia due to existence of the so-called 'Asian values' which put state (in Shintoism), society or family (Confucianism) or even religion (Buddhism) over the self. That provides a valid justification for enhancing state power at the expense of human security in a traditional western sense. The same is the case in many other parts of the world. Sometimes there are real foundations for such a divergence in values. Sometimes it is artificially created. State sponsored social constructs like 'traditional values' including prevalence of the state over the individual freedoms, so-called 'moral conservatism' which includes negligence to individual freedoms (both from fear and from wants) and which postulates state sovereignty and state value as a "sacred values" embedded into the Russian's psyche (in spite of the fact that the majority of population views as centuries before the state as a major source of threats to their security) are now developing in growing scale in Russia.

East Asia as well as Eurasia (that is a larger part of the world territorially and in population) is remaining a state-centric environment, resistant to concepts of universalism and collective security, where most countries strongly defend traditional concepts of national sovereignty and resist foreign intervention into internal affairs of states. In East Asia this is in part a result of post-colonial state building. In Russia it is an inheritance of long struggle for state survival in face of external enemies. So, we can easily identify non-western (and sometimes even anti-western) traditions with regard to interrelations between states and their citizens.

However under the present conditions the only good governance possible is limited governance. The only good state is small or weak (comparing to non-state regulative mechanisms) state. As an East Asian cases have shown us sometimes it is better to have big but "weak" state which is intentionally leaves social welfare to people (social welfare system in the Kingdom of Thailand is a good example of this) than to have the state strong enough to confiscate its population social welfare savings in pension funds for its own current consumption (the case of Russia which is undergoing pension reform aimed now at confiscation of people's welfare).

Only such an approach could allow for symbiotic (as opposing to parasitic) relations between people (and society) and states, between state security and human security. Good governance is not always (or better to say, rarely) the state governance. Sometimes could be viewed as a process that is not coinciding with government (or sometimes is opposing it). So, non-state (or even anti-state) mechanisms of governance and good governance for the promotion of human security should be explored more in a future research of transformation of state.

\section{References}

Avralev, N. \& Efimova, I. (2013). The Role of the International University Network Organizations in the Innovative Development of Russia. Middle-East Journal of Scientific Research, 14(10), 1277-1291.

Avralev, N., \& Efimova, I. (2013). University Rankings as a Tool to Enhance Competitiveness, Clustering and Transnational Governance of Higher Education in the Context of Globalization. Middle-East Journal of Scientific Research, 16(3), 357-361.

Avralev, N., \& Efimova, I. (2014). Global university rankings as indicators of the implementation of the integration process and competitive tool in the context of globalization of higher education. Life Sci J., $11(10), 648-652$.

Baluev, D. (2013). Political role of social media as a field of research. Educational Technology \& Society, 16(2).

Baluev, D., \& Novoselov, A. (2010). The "gray zones" of world politics. Essays on Current Politics (Issue 3). Moscow: Academic Educational Forum on International Relations. Retrieved January 10, 2010, from http://obraforum.ru/lecture.htm

Brooks, R. (2012). Strange Bedfellows the Convergence of Sovereignty-Limiting Doctrines in Counterterrorist and Human Rights Discourse. Georgetown Journal of International Affairs, 13(2).

Buzan, B. (1996). The Timeless Wisdom of Realism? In S. Smith, K. Booth, \& M. Zalewski (Eds.), International Theory: Positivism and Beyond (pp. 47-65). Cambridge University Press. http://dx.doi.org/10.1017/ CBO9780511660054.004

Carothers, T., \& Youngs, R. (2011). Looking for Help: Will rising Democracies become international Democracy Supporters? Carnegie Endowment for International Peace. Democracy and rule of law.

Castells, M. (1998). The Power of Identity (p. 303). Blackwell Publishers.

Chong, J. I. (2011). How External Intervention Made the Sovereign State. Security Studies, 19(4), 623-624. http://dx.doi.org/10.1080/09636412.2010.524074

Finnemore, M. (1996). National Interests in International Society (p. 2). Cornell University Press. 
Held, D., McGrew, A., Goldblat, D., \& Parraton, J. (1999). Global Transformations (p. 65). Cambridge: Polity Press.

Ikenberry, G. J. (2011). The Future of the Liberal World Order. Foreign Affairs, 90(3).

Kivimäki, T. (2012). Sovereignty, hegemony, and peace in Western Europe and in East Asia. International Relations of the Asia-Pacific, 12, 419-447. http://dx.doi.org/10.1093/irap/lcs003

LAÏDI, Z. (2011). The BRICS against the West? CERI Strategy Papers. No 11 - Hors Série.

Lake, D. A. (1999). Global Governance. A Relational Contracting Approach. In A. Prakash, \& J. A. Hart (Eds.), Globalization and Governance (p. 31). Routledge.

Reinicke, W. H. (2000). The Other World Wide Web: Global Public Policy Networks. Foreign Policy, 117, 44-56.

Rosenau, J. (1989). Global Changes and Theoretical Challenges: Towards a Post-International Politics for 1990's. In E. O. Czempiel, \& J. Rosenau (Eds.), Global Changes and Theoretical Challenges. Lexington: Lexington Books.

Rykhtik, M. I. (2012). Policy of multiculturalism and especially foreign experience in regulating the problems associated with the intensification of migratory flows. Bulletin of the Bashkir University, 17(1), 388-391.

Sergounin, A. A. (1996). An age of uncertainty: Building a post-cold war U.S. security strategy for East and Southeast Asia. East Asia, 15(2), 25-49.

Smith, S., Booth, K., \& Zalewski, M. (Eds.). (1996). International Theory: Positivism and Beyond. Cambridge University Press. http://dx.doi.org/10.1017/CBO9780511660054

Strange, S. (2000). The Defective State. In R. Higgot, \& A. Payne (Eds.), The New Political Economy of Globalization (Vol. 1. p. 270). Cheltenham, UK-Northampon, MA: AnElgar Reference Collection.

Thurman, P. W., \& Efimova, I. (2014). Use of rankings to improve global competitiveness of Russian's higher education institutions and technology exports. Life Sci J, 11(11), 285-289.

Tsygankov, P. A. (2000). Security: Cooperative or corporate. Critical analysis of the international political concept, Policy number(3), 130.

Underhil, G. R. D. (2000). Global Money and the Decline of State Power. In T. C. Lawton, J. N. Rosenau, \& A. C. Verdun (Eds.), Strange Power, Shaping the Parameters of IR and IPE (p. 122). Ashgate.

Waldron, J. (2011). Are Sovereigns Entitled to the Benefit of the International Rule of Law? European Journal of International Law, 22(2). http://dx.doi.org/10.1093/ejil/chr031

Wilhelm, A.G. (2000). Democracy in a digital age. London: Routlege.

Youngs, G. (1999a). International Relations in a Global Age (pp. 1-11). Cambridge: Polity Press.

Youngs, G. (1999b). International Relations in a Global Age (pp. 71-72). Polity Press.

\section{Copyrights}

Copyright for this article is retained by the author(s), with first publication rights granted to the journal.

This is an open-access article distributed under the terms and conditions of the Creative Commons Attribution license (http://creativecommons.org/licenses/by/3.0/). 